\title{
STUDI LITERATUR : OBESITAS SEBAGAI FAKTOR RESIKO TERHADAP KEJADIAN UROLITIASIS SECARA KLINIS
}

\author{
Literature Review : Obesity as risk factor for Clinical Urolithiasis Occurrence
}

\author{
Hasnawati ${ }^{\text {* }}$ \\ Elsa Trinovita ${ }^{2}$ \\ Yudi Y Ambeng ${ }^{2}$ \\ *I Mahasiswa Program Studi \\ Pendidikan Dokter, Fakultas \\ Palangka Raya, Universitas \\ Palangka Raya, Palangka Raya, \\ Kalimantan Tengah, Indonesia \\ 2 Dosen Pengajar Program Studi \\ Pendidikan Dokter, Fakultas \\ Palangka Raya, Universitas \\ Palangka Raya, Palangka Raya, \\ Kalimantan Tengah, Indonesia
}

*email :

hasnae1509@gmail.com

\begin{abstract}
Abstrak
Kejadian urolitiasis cenderung relapse sehingga menyebabkan peningkatan mortalitas dan biaya pengobatan. Pada tahun 20I5, terdapat 22,I juta kasus urolitiasis yang menyebabkan kematian pada sekitar 16.000 orang. Obesitas merupakan salah satu faktor risiko yang dapat meningkatkan kejadian urolitiasis. Namun, terdapat perbedaan hasil penelitian mengenai hubungan obesitas dengan kejadian urolithiasis. Tujuan dilakukan literature review ini adalah untuk menganalisis faktor-faktor yang mempengaruhi hubungan obesitas dengan kejadian urolitiasis. Penelitian literature review ini menggunakan desain systematic review. Sumber data yang digunakan dalam literature review ini adalah data sekunder berupa jurnal ilmiah yang telah memenuhi kriteria inklusi dan ekslusi. Berdasarkan sintesis data, dari lima belas jurnal yang dikaji, terdapat dua belas jurnal yang menyatakan bahwa terdapat hubungan antara obesitas dengan kejadian urolitiasis, sedangkan tiga lainnya menyatakan tidak terdapat hubungan antara obesitas dengan kejadian urolitiasis. Obesitas berkaitan dengan spektrum kelainan metabolisme yang menyebabkan peningkatan ekskresi faktor litogenik urin. Selain itu, obesitas dapat meningkatkan risiko urolitiasis pada jenis batu kalsium oksalat dan batu asam urat.
\end{abstract}

\begin{abstract}
The incidence of urolithiasis tends to relapse, causing increased mortality and medical costs. In 2015, there were 22.1 million cases of urolithiasis which caused death in about 16,000 people. Obesity is a risk factor that can increase the incidence of urolithiasis. However, there are differences in the results of studies regarding the relationship between obesity and urolithiasis. The purpose of this literature review is to analyze the factors that influence the relationship between obesity and urolithiasis. This literature review study uses a systematic review design. The data source used in this literature review is secondary data in the form of scientific journals that have met the inclusion and exclusion criteria. Based on data synthesis, from the fifteen journals studied, there were twelve journals which stated that there was a relationship between obesity and the incidence of urolithiasis, while the other three stated that there was no relationship between obesity and the incidence of urolithiasis. Obesity is associated with a spectrum of metabolic disorders that lead to increased excretion of urinary lithogenic factor. In addition, obesity can increase the risk of urolithiasis in types of calcium oxalate and uric acid stones.
\end{abstract}

\author{
Kata Kunci: \\ Batu Saluran Kemih \\ Batu Ginjal \\ Keywords: \\ Risk Factors \\ Kidney stones \\ Metabolic syndrom
}

\section{PENDAHULUAN}

Urolitiasis adalah pembentukan batu saluran kemih, atau keadaan yang berkaitan dengan adanya batu di saluran kemih (Dorland, 20I5). Batu yang ditemukan pada ginjal disebut nefrolitiasis, dan kasus ini yang paling sering ditemukan. Pada tahun 2015, terdapat $22, \mathrm{I}$ juta kasus urolithiasis yang menyebabkan kematian pada sekitar 16.000 orang di dunia. Prevalensi urolithiasis di Asia sekitar 1\% - 19,1\% dari populasi (Liu et al, 20I8). Di Indonesia, diperkirakan bahwa prevalensi penderita batu ginjal sebesar 0,6\% atau 6 per 1000 penduduk. Meski begitu, penyakit batu saluran kemih di Indonesia masih menempati porsi terbesar dari jumlah pasien di klinik urologi 
(Kurniawan dan Djojodimedjo, 2020). Berdasarkan data yang diperoleh dari Instalasi Rekam Medik RSUD dr. Doris Sylvanus Palangka Raya, terdapat 70 kasus baru urolitiasis pada tahun 2018 (Indriani, 2019).

Penyakit BSK merupakan penyakit yang cenderung relapse, angka kekambuhan BSK dalam satu tahun I5$17 \%$, 4-5 tahun $50 \%$, 10 tahun $75 \%$ dan $95-100 \%$ dalam 20-25 tahun. Jika BSK kambuh, maka dapat terjadi peningkatan mortalitas dan peningkatan biaya pengobatan. Manifestasi klinis urolithiasis dapat berbentuk rasa sakit yang ringan sampai berat dan komplikasi seperti urosepsis dan gagal ginjal. Urolitiasis yang masih berukuran kecil umumnya tidak menunjukkan gejala yang signifikan, namun perlahan seiring berjalannya waktu dan perkembangan di saluran kemih akan menimbulkan gejala seperti rasa nyeri (kolik renalis) di punggung, atau perut bagian bawah (Lina, 2008).

Secara epidemiologis terdapat dua faktor yang mempermudah terjadinya urolitiasis, yaitu faktor intrinsik dan ekstrinsik. Faktor intrinsik merupakan faktor yang berasal dari diri individu sendiri seperti usia, genetik, dan jenis kelamin. Faktor ekstrinsik adalah faktor yang berasal dari luar individu seperti jumlah asupan air, diet, hipertensi, merokok, kebiasaan menahan kemih, aktivitas fisik, dan obesitas (Srinivas et al, 2012; Sulistiyowati et al, 2013; Soueidan et al, 2015; Trisnawati et al, 2018). Obesitas merupakan salah satu faktor risiko yang dapat meningkatkan kejadian urolitiasis. Obesitas didefinisikan sebagai akumulasi lemak abnormal atau berlebihan yang menghadirkan risiko bagi kesehatan, termasuk kesehatan sistem perkemihan. Pada tahun 2016, lebih dari 650 juta orang dewasa atau sekitar 13\% orang dewasa di dunia mengalami obesitas (WHO, 2020).

Penelitian yang dilakukan Ghazaleh dan Budair mengatakan bahwa terdapat hubungan yang jelas antara obesitas dan urolitiasis, dimana mayoritas pasien batu saluran kemih mengalami obesitas (Ghazaleh dan Budair, 20I3). Hal itu sejalan dengan penelitian yang dilakukan Sofia et al yang mengatakan bahwa sebesar $54 \%$ pasien urolithiasis mengalami obesitas (Sofia et al, 2016) Namun, penelitian yang dilakukan oleh Agustin et al menyatakan sebaliknya, bahwa tidak terdapat hubungan antara obesitas dengan pembentukan batu salran kemih (Agustin et al, 2019). Hasil penelitian Nurfitriani dan Oka juga menyatakan bahwa obesitas tidak memiliki hubungan terhadap kejadian urolitiasis (Nurfitriani dan Oka, 20l4). Perbedaan hasil penelitian mengenai hubungan obesitas dengan kejadian urolithiasis mendorong penulis untuk melakukan literature review yang berjudul "Hubungan Obesitas dengan Kejadian Urolitiasis". Hasil literature review ini diharapkan memberikan wawasan baru bagi penulis dan bagi masyarakat diharapkan dapat meningkatkan kewaspadaan terhadap risiko urolithiasis sehingga dapat mengambil tindakan pencegahan sedini mungkin.

\section{METODOLOGI}

Jenis penelitian ini adalah penelitian literature review dengan desain systematic review. Sumber data yang digunakan dalam literature review ini adalah data sekunder berupa jurnal ilmiah. Kriteria inklusi meliputi jangka waktu terbitnya jurnal maksimal 10 tahun (20I I-2020), bahasa yang digunakan dalam jurnal yaitu bahasa Inggris atau bahasa Indonesia, jenis jurnal merupakan original article, dan tema bahasan jurnal adalah hubungan obesitas dengan urolitiasis. Kriteria eksklusi meliputi jurnal merupakan literature review, dan jurnal tidak tersedia full text. Pada literature review ini, sintesis data dilakukan dengan mengelompokkan datadata hasil ekstraksi sejenis sesuai dengan hasil yang diukur sehingga dapat menjawab tujuan dari literature review. Judul penelitian yang sesuai dengan kriteria inklusi kemudian dikumpulkan dan dibuat ringkasan jurnal meliputi judul penelitian, tahun terbit jurnal, nama peneliti, metode penelitian dan ringkasan hasil penelitian. 


\section{HASIL SINTESIS DATA}

Pada Tabel I dibawah ini menunjukkan ringkasan terkait beberapa hasil sintesis data berdasarkan penggelompokkan jurnal nasional dan jurnal internasional yang telah memenuhi kriteria inklusi yang telah ditentukan.

\section{Tabel I. Hasil Sintesis Data}

\begin{tabular}{cl} 
No. & Referensi \\
\hline l. & Sorensen et al, 2014
\end{tabular}

I. Sorensen et al, 2014

2. Shrivastava et al, 2016

3. Almannie et al, 2020

4. Fazriyah et al, 2019

5. Najeeb et al, 2013

6. Shavit et al, 2015

\section{Metode Penelitian}

Studi Observasional, kohort prospektif, pada wanita post-menopause yang terdaftar dari 1993 hingga 1998 dengan median follow up selama 8 tahun. Hubungan aktivitas fisik, asupan energi makanan, dan indeks massa tubuh (IMT) dengan insiden perkembangan batu ginjal dievaluasi.

Sebanyak 100 pasien yang menjalani prosedur bedah terbuka untuk urolitiasis diteliti. Penelitian dilakukan dari Oktober 2013 hingga Oktober 20I4. Hubungan IMT dengan $\mathrm{pH}$ urin, kreatinin serum, asam urat serum, kalsium serum, dan komposisi kimia batu dianalisis.

Studi retrospektif pada 433 pasien yang menjalani analisis batu saluran kemih dengan spektroskopi inframerah transformasi Fourier di RS Universitas King Khalid di Riyadh dari Mei 2015 hingga Juni 2017. Pemeriksaan IMT dilakukan.

Jenis penelitian Cross sectional dengan Chi-square dan regresi logistik multivariat untuk analisis data dari data sekunder Riskesdas 2013 dengan 26.063 responden. Diagnosis batu ginjal berdasarkan wawancara Riskesdas 2013, sindrom metabolik berdasarkan NCEP ATP-III dan PERKENI.

Penelitian ini dilakukan di Departemen Biokimia, Institut Penelitian dan IImu Kedokteran Maharishi Markandeshwar, pada 100 pasien urolitiasis. Data termasuk usia pasien, jenis kelamin, IMT, pH urin, kalsium serum, asam urat serum, kreatinin serum dan komposisi batu didapatkan.

Pasien batu ginjal yang menghadiri klinik batu metabolik besar diselidiki. Pasien berjumlah 2I32. Pasien dibagi menjadi tiga kategori: IMT $\leq 25,0 \mathrm{~kg} / \mathrm{m} 2$ (kelompok normal weight), IMT $25-30 \mathrm{~kg} / \mathrm{m} 2$ (kelompok overweight) dan IMT> 30,0 kg / m2 (kelompok obesitas). Volume urin dua puluh empat jam (U.Vol), pH (U.pH), kalsium (U.Ca), oksalat (U.Ox), sitrat (U.Cit), asam urat (U.UA), magnesium (U.Mg), natrium (U.Na) dan kalium (U.K), bersama dengan komposisi batu dan PSF (probability of

\section{Hasil Penelitian}

Dari 84.225 wanita, 2392 melaporkan kejadian batu ginjal. IMT, asupan energi makanan, dan aktivitas fisik dikaitkan dengan kejadian batu ginjal.

Hasil penelitian menunjukkan adanya peningkatan signifikan pada keberadaan batu kalsium oksalat dan asam urat dengan peningkatan IMT. Kehadiran batu kalsium fosfat tidak menunjukkan adanya perubahan signifikan dengan perubahan IMT.

Kejadian urolitiasis dengan jenis batu kalsium oksalat dan batu asam urat lebih tinggi pada pasien dengan IMT di atas tiga puluh dibandingkan pada pasien dengan IMT lebih rendah.

Obesitas sentral merupakan faktor dominan yang berhubungan dengan risiko terjadinya batu ginjal pada laki-laki, dan sindrom metabolik merupakan faktor dominan yang berhubungan dengan risiko terjadinya batu ginjal pada wanita.

Sebanyak 28 pasien memiliki berat badan normal, 38 pasien overweight dan 34 pasien obesitas. Komposisi batu kalsium oksalat pada 66 pasien, kalsium fosfat pada 60 pasien, asam urat pada 38 pasien, kombinasi kalsium oksalat dan kalsium fosfat pada 28 pasien dan tiga batu pada 10 pasien. PH urin berbanding terbalik dengan IMT pada pasien.

Tidak ada perbedaan yang signifikan secara statistik pada U.Vol dan U.Mg di antara kelompok. Namun, tingkat U.Ca, U.Ox, U.Cit secara signifikan lebih tinggi, U.UA, U.Na, dan U.pH lebih rendah ditunjukkan pada overweight dan obesitas. Data komposisi batu menunjukkan insiden batu asam urat yang secara signifikan lebih tinggi pada kelompok overweight dan obesitas. Selain itu, PSF yang lebih tinggi untuk jenis batu $\mathrm{CaOx}, \mathrm{UA}$. 
7. Agustin et al, 2019 Penelitian dilakukan secara case control dengan purposive sampling sesuai dengan kriteria yang telah ditetapkan pada bulan Februari-Maret 2019. Jumlah sampel 122 orang yang terdiri dari 61 pasien dengan batu saluran kemih sebagai kelompok kasus dan 61 pasien selain batu saluran kemih sebagai kelompok kontrol. Pengumpulan data dilakukan secara primer oleh peneliti dengan mengukur tekanan darah dan Indeks Massa Tubuh pasien setelah didiagnosis oleh dokter spesialis urologi di poliklinik urologi RSUD Abdul Wahab Sjahranie Samarinda.

8. $\quad$ Anhar dan Widianto, 2014 Penelitian ini merupakan penelitian studi analitik observasional retrospektif dengan menggunakan metode cross sectional. Penelitian ini menggunakan data sekunder, yaitu data yang telah direkapitulasi oleh bagian rekam medik di Rumah Sakit Muslimat Ponorogo periode Januari 2007 - Desember 2010 dengan pasien terdiagnosis penyakit batu saluran kemih.

9. Wrobel et al, 2011 Sebanyak 100 pasien urolitiasis dengan $\mathrm{CaOx}$ murni dipelajari. Berdasarkan IMT,
pasien dibagi menjadi tiga kelompok: (I) IMT $\leq 25$; (2) IMT 25, I-30; (3) IMT > 30

\section{I0. Sofia et al, 2016}

Sebanyak 666 pasien mengunjungi OPD-I, Dept. of Maruthuvam, National Institute of Siddha dari November 2013 hingga Oktober 2014 diteliti. Studi ini menggunakan kuesioner yang meliputi kekambuhan pembentukan batu, riwayat keluarga, asupan air, kelebihan berat badan dan obesitas, kebiasaan diet, hubungan modifikasi gaya hidup dengan penyakit lain (Hipertensi, Diabetes dan ISK).

II. Ghazaleh dan Budair, $2013 \quad$ Studi retrospektif pada semua pasien dengan urolitiasis di klinik di Pusat Urologi Pangeran Hussein Bin Abdullah dan Pusat Transplantasi di Pusat Medis King Hussein, Royal Medical Services, Yordania, selama 5 tahun. Usia pasien, jenis kelamin, IMT,

jumlah kunjungan ke klinik dan jumlah intervensi bedah dianalisis.

12. Mostafavi et al, 2018 dewasa dengan urolitiasis yang didiagnosis dengan CT scan dari Oktober 2014 hingga September 2016. Kelompok kontrol terdiri dari 100 orang dewasa yang datang ke rumah sakit karena trauma, tanpa riwayat medis penyakit urologi sebelumnya, yang menjalani CT scan perutinopelvis. Area lemak viseral dan parameter terkait obesitas
Hasil tabulasi silang indeks massa tubuh dengan batu saluran kemih mendapatkan hasil bahwa tidak terdapat hubungan antara nilai IMT dengan penyakit batu saluran kemih. Hasil penelitian ini tidak sesuai dengan hipotesis penelitian

Prevalensi urolitiasis pada setiap indeks massa tubuh adalah $28,3 \%$ pada IMT tinggi, 72,9\% pada IMT tubuh normal dan 16,6\% pada IMT rendah. Dari 120 sampel yang dianalisis dengan Chi-square didapatkan hasilnya tidak ada hubungan antara indeks massa tubuh dengan urolitiasis.

Sebanyak 32 pasien menunjukkan IMT $\leq 25,42$ pasien menunjukkan IMT 25-30 dan 26 pasien menunjukkan IMT $\geq 30$. Penelitian ini menunjukkan bahwa berat badan berlebih merupakan faktor risiko dari batu kalsium oksalat.

Dari 666 pasien, sebanyak 288 (43,24\%) pasien sudah menderita batu selama hidupnya, $154(23,12 \%)$ pasien memiliki riwayat keluarga batu ginjal, 480 (72,07\%) kurang asupan cairan, 450 (67,56\%) pasien banyak berkeringat setiap hari, 165 (24,77\%) pasien sering menggunakan NSAID untuk nyeri, dan 365 (54,80\%) pasien mengalami obesitas.

Selama periode 60 bulan, 8346 pasien dirawat karena urolitiasis. 42,3\% mengalami obesitas dan $25,8 \%$ kelebihan berat badan, sedangkan hanya $31,9 \%$ memiliki berat badan normal.

Hasil penelitian menunjukkan bahwa obesitas, khususnya obesitas viseral, berhubungan dengan penyakit batu saluran kemih. Individu dengan obesitas berat berisiko lebih tinggi mengalami pembentukan batu saluran kemih dibandingkan individu dengan obesitas ringan. 
lainnya diukur dengan menggunakan CT scan, pada satu potongan melintang setinggi umbilikus.

13. Nurfitriani dan Oka, 20I4 Penelitian observasi analitik dengan teknik cross-sectional. Pasien dengan diagnosa BSK yang terdaftar di poli urologi RSUP Sanglah Denpasar dengan kurun waktu Januari hingga Desember 2014 merupakan populasi dari penelitian ini yang memenuhi kriteria inklusi. Apabila data faktor risiko yang nantinya akan digunakan seperti umur dan indeks massa tubuh tidak terdapat pada rekam medis, maka ini dimasukkan sebagai kriteria eksklusi. Sumber data sampel penelitian berasal dari data sekunder yang diambil dari rekam medis pada tahun 2014
Sebanyak 109 anak dengan urolitiasis, berusia 9-18 tahun (rata-rata: 13 tahun), terdaftar dalam penelitian ini. Para pasien dibagi menjadi dua kelompok: Kelompok I anak-anak dengan massa tubuh normal, dan Kelompok II - anak-anak dengan massa tubuh tinggi. Sampel darah dan urine dikumpulkan dan diuji di laboratorium untuk mengetahui penyebab urolitiasis. Selain itu, parameter antropometri yang dievaluasi meliputi indeks massa tubuh, lingkar pinggang, rasio pinggang-pinggul, massa tubuh, dan tinggi badan.

Sebanyak 149 pasien dengan keluhan nyeri pinggang dan batu ginjal terdeteksi oleh CT, dari Agustus 2012 hingga April 2013. Selain itu, 139 individu sehat sebagai kelompok kontrol, dengan nyeri pinggang dalam periode waktu yang sama, tanpa riwayat penyakit urologi sebelumnya dan tidak ada batu ginjal yang diidentifikasi dengan CT. Pasien dianalisis untuk usia, jenis kelamin, indeks massa tubuh, jumlah jaringan adiposa visceral dan subkutan, dan kadar serum lipoprotein densitas rendah dan trigliserida.
Responden terkait obesitas di RSUP Sanglah proporsi non obese lebih tinggi yang tidak mengalami BSK yaitu sebanyak 40 responden dibandingkan yang mengalami BSK sebanyak 37 responden. Proporsi obese lebih tinggi yang mengalami BSK yaitu sebanyak 17 responden dan yang tidak mengalami BSK sebanyak 14 responden. Responden dengan obese memiliki kemungkinan I kali untuk mengalami BSK daripada responden dengan non obese dan secara statistik tidak bermakna.

Anak-anak dengan massa tubuh tinggi ditemukan memiliki kadar asam urat serum yang lebih tinggi secara statistik dan ekskresi asam urat urin yang secara signifikan lebih tinggi dibandingkan dengan anak-anak dengan massa tubuh normal. Ada kemungkinan korelasi antara kelebihan berat badan dan urolitiasis terkait dengan ekskresi asam urat yang berlebihan.

Rasio jaringan adiposa viseral ke subkutan, obesitas, hiperlipidemia, dan hipertensi, diidentifikasi sebagai faktor yang muncul dalam pembentukan batu ginjal. 
Berdasarkan sintesis data, didapatkan sebanyak dua belas jurnal (80\%) yang menyatakan bahwa terdapat hubungan bermakna antara obesitas dengan urolitiasis, dan tiga jurnal (20\%) yang menyatakan bahwa tidak ada hubungan bermakna antara obesitas dengan urolitiasis. Persentase hubungan obesitas dengan kejadian urolitiasis dapat dilihat dari Gambar I di bawah ini.

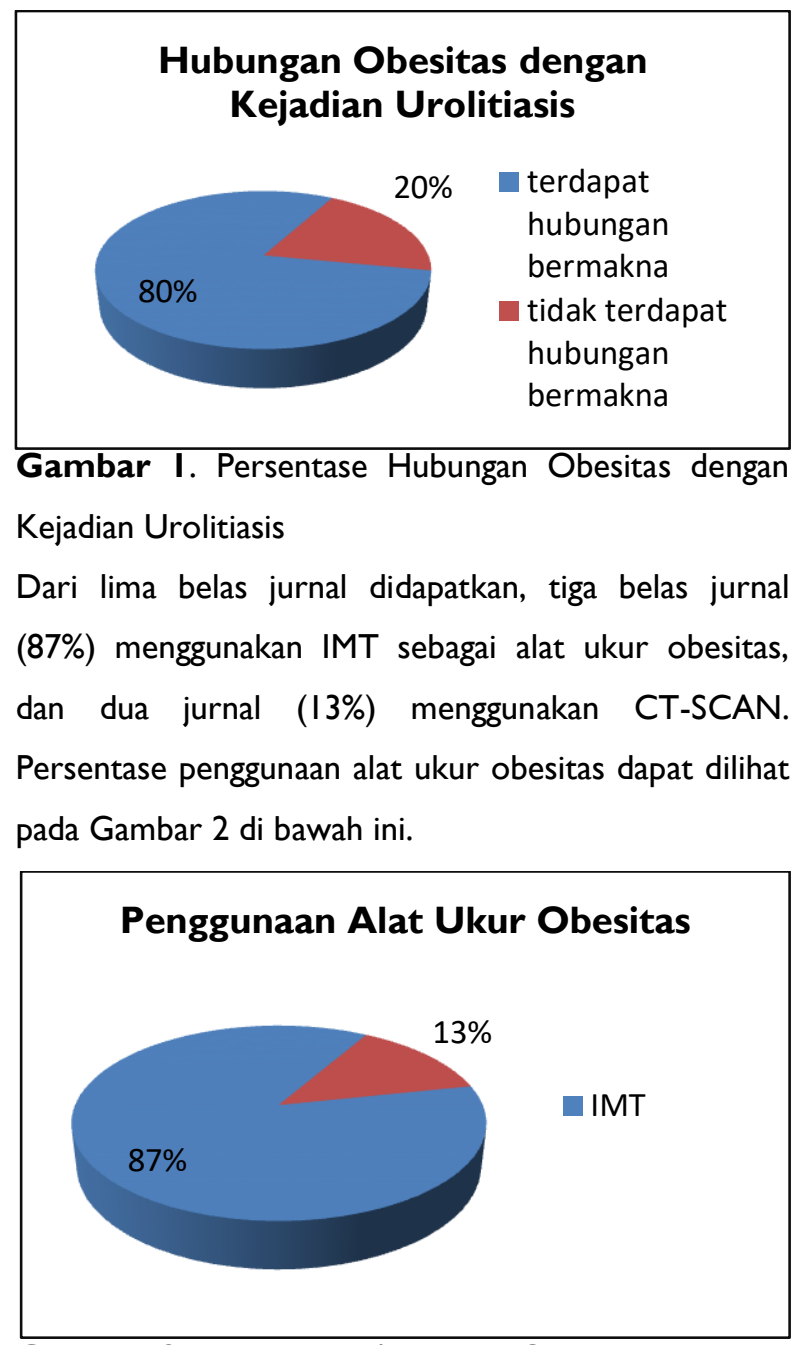

Gambar 2. Penggunaan Alat Ukur Obesitas

\section{PEMBAHASAN}

Batu saluran kemih merupakan penyakit multifaktorial yang salah satu faktor yang mempengaruhinya adalah obesitas. Berdasarkan penelitian, obesitas dikaitkan dengan spektrum kelainan metabolisme yaitu dislipidemia, hipertensi, gangguan toleransi karbohidrat, resistensi insulin dan hiperinsulinemia. Kondisi-kondisi tersebut membentuk Sindrom
Metabolik. Berdasarkan hipotesis yang telah dikemukakan oleh para peneliti, peningkatan prevalensi sindrom metabolik menambah kecenderungan pembentukan batu asam urat dan kalsium oksalat. Resistensi insulin adalah kondisi umum pada obesitas, diabetes tipe 2, dan sindrom metabolik yang diduga menyebabkan $\mathrm{pH}$ urin terlalu asam dalam tubuh pasien. Hiperinsulinemia juga dapat menyebabkan penurunan sitrat urin, peningkatan ekskresi kalsium, asam urat dan oksalat urin yang merupakan faktor risiko penting untuk nefrolitiasis (Shavit et al, 2015).

Umumnya, urolitiasis menyerang lebih banyak pada orang dewasa. Namun, dalam beberapa tahun terakhir semakin banyak didiagnosis pada populasi anak. Dalam penelitian pada pasien anak, anak-anak dengan massa tubuh tinggi dan urolitiasis ditemukan memiliki kadar asam urat serum yang lebih tinggi secara signifikan. Selain itu, ekskresi asam urat secara signifikan lebih tinggi ditemukan dalam sampel urin yang diperiksa. Hasil penelitian menyatakan bahwa ada kemungkinan korelasi antara kelebihan berat badan dan urolitiasis terkait dengan ekskresi asam urat yang berlebihan (Sopińska et al, 2019)

Penelitian yang dilakukan oleh Shrivastava et al dan Almannie et al menemukan korelasi positif antara pembentukkan batu kalsium oksalat dan batu urat dengan obesitas. Kejadian urolitiasis dengan jenis batu kalsium oksalat dan batu asam urat lebih tinggi pada pasien dengan IMT lebih dari tiga puluh atau dikategorikan sebagai obesitas (Shrivastava et al, 2016; Almannie et al, 2020). Hal ini juga sejalan dengan studi terbaru pada tahun 2020 yang menunjukkan bahwa berat badan berlebih merupakan faktor risiko pada pembentukan batu kalsium oksalat (Wrobel et al, 20II). Penjelasan yang mungkin untuk peningkatan kalsium oksalat dan batu asam urat pada pasien dengan IMT tinggi mungkin karena asam urat urin berkontribusi secara substansial terhadap risiko pembentukan batu kalsium oksalat karena konsentrasi asam urat yang tinggi menyebabkan penurunan 
kelarutan kalsium oksalat dan mungkin terkait dengan aktivitas penghambatan yang berkurang dari glikosaminoglikan pada kristalisasi kalsium oksalat (Shrivastava et al, 2016)

Overweight sangat lazim dan sebenarnya merupakan subkelompok terbesar dari pasien urolitiasis. Peningkatan bertahap dan signifikan pada prevalensi diabetes, hipertensi dan asam urat terdeteksi pada pasien overweight dan obesitas. Studi ini menunjukkan beberapa perubahan dalam profil metabolik urin pada pasien batu saluran kemih yang terkait dengan peningkatan risiko keseluruhan pembentukan batu. Faktor risiko utama ini tampaknya disebabkan oleh peningkatan ekskresi asam urat dan natrium melalui urin, prevalensi hiperkalsiuria yang lebih tinggi, dan urin yang lebih asam. volume urin, sitrat dan ekskresi magnesium tidak dipengaruhi oleh IMT yang lebih tinggi. Hal itu menyebabkan ketidakseimbangan antara penggerak dan penghambat litogenesis dalam urin pada pasien batu saluran kemih dengan obesitas. Khususnya, penelitian ini menunjukkan proporsi asam urat yang meningkat secara signifikan. Prevalensi dan keparahan perubahan biokimia berkorelasi positif dengan peningkatan IMT. Pasien overweight dan obesitas dalam penelitian ini menunjukkan peningkatan prevalensi fitur sindrom metabolik. Selain obesitas, pasien hadir dengan dominasi diabetes, hipertensi dan dislipidemia yang lebih tinggi. Potensi hubungan patogenik faktor metabolik meningkatkan resistensi insulin, serta pembentukan batu dalam urin, faktor lingkungan seperti diet, stres oksidatif dan peradangan dan perubahan molekuler yang mempengaruhi pengangkutan beberapa analit dalam urin. Penelitian ini menunjukkan bahwa kelebihan berat badan dikaitkan dengan sindrom metabolik dan peningkatan ekskresi faktor litogenik urin, dan mendukung bukti bahwa nefrolitiasis terkait sindrom metabolik dapat dianggap sebagai gangguan sistemik multifaktorial yang membutuhkan pendekatan multidisiplin untuk pencegahan dan manajemen (Shavit et al, 2015).
Penelitian yang dilakukan oleh Najeeb et al menyimpulkan bahwa $\mathrm{pH}$ urin berbanding terbalik dengan IMT di antara pasien urolitiasis, pasien dengan berat badan berlebih memiliki $\mathrm{pH}$ urin yang lebih rendah. Alasan penurunan progresif pada $\mathrm{pH}$ urin dengan peningkatan IMT pada pasien urolitiasis tidak pasti. Hiperinsulinemia atau resistensi insulin adalah salah satu kemungkinan penyebabnya. Resistensi insulin dapat bermanifestasi di ginjal sebagai kerusakan pada produksi amonium dan kemampuan untuk mengeluarkan asam, dan dengan demikian mempengaruhi $\mathrm{pH}$ urin. Hasil yang disebutkan di atas dapat menjelaskan mengapa obesitas dikaitkan dengan peningkatan risiko urolitiasis. Keterbatasan penelitian ini adalah tidak memiliki informasi mengenai biokimia urin pasien sehingga tidak dapat menganalisis hubungan antara IMT dan faktor litogenik pada berbagai jenis batu (Najeeb et al, 20।3)

Penelitian selanjutnya membahas tentang hubungan obesitas visceral dengan urolitiasis. Visceral fat area (VFA) lebih tepat daripada IMT dalam evaluasi risiko sindrom metabolik. Semua parameter terkait obesitas secara signifikan lebih tinggi pada pasien penyakit batu kemih dibandingkan pada subjek kontrol. Hasil ini menunjukkan bahwa obesitas, khususnya obesitas viseral, berhubungan dengan penyakit batu saluran kemih. Individu dengan obesitas berat berisiko lebih tinggi mengalami pembentukan batu saluran kemih dibandingkan individu dengan obesitas ringan. Studi lain juga menunjukkan bahwa obesitas viseral merupakan faktor risiko yang signifikan pada urolitiasis (Mostafavi et al, 20 I8; Akarken et al, 20I5)

Hasil studi cross-sectional pada populasi umum di Indonesia melaporkan bahwa obesitas sentral merupakan faktor dominan yang berhubungan dengan risiko terjadinya batu ginjal pada laki-laki, dan sindrom metabolik merupakan faktor dominan yang berhubungan dengan risiko terjadinya batu ginjal pada wanita. Sindrom Metabolik didiagnosis berdasarkan kriteria National Cholesterol Education Program Adult 
Treatment Panel III (NCEP ATP III) dan Perhimpunan Endokrinologi Indonesia (PERKENI) yang telah disesuaikan untuk masyarakat Indonesia. Sindrom metabolik dalam penelitian ini didefinisikan sebagai mereka yang memenuhi setidaknya tiga dari lima parameter berikut: lingkar pinggang $>90 \mathrm{~cm}$ untuk pria dan $>80 \mathrm{~cm}$ untuk wanita untuk obesitas sentral, hipertensi (tekanan darah $>140 / 90 \quad \mathrm{mmHg}$ ), hiperglikemia (glukosa darah puasa $\geq 126 \mathrm{mg} / \mathrm{dL}$ ), kolesterol HDL rendah (pria $<40 \mathrm{mg} / \mathrm{dL}$ dan wanita $<50 \mathrm{mg} / \mathrm{dL}$ ), dan hiper trigliserida (trigliserida $\geq 150$ $\mathrm{mg} / \mathrm{dL}$ ) (Fazriyah et al, 2019).

Penelitian yang dilakukan Sorensen et al menyebutkan bahwa kategori IMT yang lebih tinggi dikaitkan dengan risiko yang lebih besar dari kejadian batu ginjal pada wanita pascamenopause. Namun, penyebab peningkatan risiko ini belum dipahami dengan baik. Studi ini menunjukkan bahwa IMT merupakan faktor risiko dari kejadian batu ginjal. Penelitian ini memiliki beberapa keterbatasan, yaitu populasi penelitian hanya pada wanita pascamenopause, dan temuan ini mungkin berbeda pada pria atau wanita yang lebih muda (Sorensen et al, 20l4). Hal ini sejalan dengan studi retrospektif yang melibatkan 8346 pasien selama 60 bulan. Pada studi ini didapatkan 42,3\% mengalami obesitas dan 25,8\% kelebihan berat badan, sedangkan hanya 31,9\% memiliki berat badan normal. Pada studi ini juga ditemukan bahwa jumlah wanita secara signifikan lebih tinggi pada kelompok overweight dan obesitas. Dari hasil di atas, bisa disimpulkan bahwa mayoritas pasien batu saluran kemih memiliki berat badan yang berlebih, dan pasien urolitiasis yang memiliki berat badan berlebih didominasi oleh wanita (Ghazaleh dan Budair, 2013). Hal ini terjadi karena prevalensi sindrom metabolik lebih tinggi pada wanita dibandingkan pria. Pada wanita, peningkatan IMT, kolesterol HDL rendah, peningkatan lingkar pinggang dan hiperglikemia secara signifikan merupakan kontributor yang lebih besar untuk sindrom metabolik, sedangkan pada pria adalah hipertensi dan peningkatan trigliserida (Beigh dan jain, 2012).

Hasil berbeda ditemukan pada penelitian yang dilakukan oleh Agustin et al yang menyatakan bahwa obesitas bukanlah faktor yang secara signifikan dapat meningkatkan risiko urolitiasis. Hasil yang berbeda juga didapatkan dari dua penelitian lainnya yang dilakukan di Indonesia. Ketiga penelitian ini menyatakan bahwa tidak terdapat hubungan antara obesitas dengan penyakit batu saluran kemih (Nurfitriani dan Oka, 2014; Anhar dan Widianto, 2014; Agustin et al, 2019).

Berdasarkan lima belas jurnal yang dikaji, terdapat dua belas jurnal yang menyatakan bahwa terdapat hubungan antara obesitas dengan kejadian urolitiasis, sedangkan tiga lainnya menyatakan tidak terdapat hubungan antara obesitas dengan urolitiasis. Perbedaan hasil kemungkinan disebabkan karena obesitas bukanlah faktor tunggal penyebab batu saluran kemih, terdapat faktor lain yang dapat menyebabkan terjadinya batu saluran kemih karena batu saluran kemih merupakan penyakit mutifaktorial. Selain itu, IMT hanyalah alat ukur sederhana untuk mengukur tingkat obesitas sehingga tidak bisa menjadi acuan yang benar-benar tepat, karena IMT tidak mampu membedakan massa otot dan lemak. Obesitas sendiri diartikan sebagai akumulasi lemak yang abnormal atau berlebihan, sehingga orang yang memiliki berat badan berlebih belum tentu memiliki akumulasi lemak berlebih. Contohnya, atlet angkat beban memiliki nilai IMT yang tinggi tetapi akumulasi lemak yang rendah. Jadi, diperlukan alat diagnostik obesitas yang lebih tepat seperti CT-scan untuk mengetahui akumulasi dan distribusi lemak yang ada di dalam tubuh. Kemudian, faktor obesitas hanya mempengaruhi beberapa jenis batu pada saluran kemih, yaitu batu kalsium oksalat, dan batu asam urat. Hal ini terjadi karena pada pasien obesitas didapatkan konsentrasi asam urat urin yang tinggi, yang menyebabkan penurunan kelarutan kalsium oksalat sehingga terjadilah urolitiasis. Keterbatasan 
pada studi yang tidak meneliti tentang jenis batu (komposisi batu) dapat juga menyebabkan perbedaan hasil penelitian.

\section{KESIMPULAN}

Berdasarkan lima belas jurnal yang dikaji, dua belas jurnal menyatakan bahwa terdapat hubungan antara obesitas dengan kejadian urolitiasis dan tiga jurnal menyatakan bahwa tidak terdapat hubungan antara obesitas dengan urolitiasis. Setelah dilakukan pengkajian dan pembahasan maka dapat disimpulkan bahwa:

I. Obesitas berkaitan dengan spektrum kelainan metabolisme yang menyebabkan peningkatan ekskresi faktor litogenik urin. Mekanisme yang mendasari bagaimana obesitas dikaitkan dengan penyakit batu ginjal sangat kompleks dan melibatkan berbagai faktor. Faktor risiko utama ini disebabkan oleh peningkatan ekskresi asam urat urin, prevalensi hiperkalsiuria yang lebih tinggi, dan $\mathrm{pH}$ urin yang rendah.

2. Obesitas dapat meningkatkan risiko urolitiasis pada jenis batu kalsium oksalat dan batu asam urat. Hal ini terjadi karena pada pasien obesitas didapatkan konsentrasi asam urat urin yang tinggi, yang menyebabkan penurunan kelarutan kalsium oksalat sehingga terjadilah urolitiasis.

\section{REFERENSI}

I. Dorland, W.A. Newman. 2015. Kamus Saku Kedokteran Dorland, ed.29. Jakarta:EGC.

2. Liu, Yu., Chen, Yuntian., Liao, Banghua., Luo, Deyi., Wang, Kunjie., Li, Hong., dan Zeng, Guohua. 2018. Epidemiology of urolithiasis in Asia, Asian Journal of Urologi. 5(4):205-2 I4.

3. Kurniawan, R., Djojodimedjo, T., dan Rahaju, S. 2020. Profile of Patients with Urinary Tract Stone at Urology Department of Soetomo General Hospital Surabaya in January 2016-December 2016, Indonesian Journal of Urology. 27(I).

4. Indriani, Miftah Dwi. 2019. Analisis Faktor Risiko Kejadian Urolitiasis di Rumah Sakit Umum Daerah dr. Doris Sylvanus Palangka Raya (Tinjauan terhadap Jenis Kelamin, Pekerjaan, dan Tekanan Darah). Skripsi. Universitas Palangka Raya.

5. Lina, Nur. 2008. Faktor-Faktor Risiko Kejadian Batu Saluran Kemih Pada Laki-Laki (Studi Kasus di RS Dr. Kariadi, RS Roemani dan RSI Sultan Agung Semarang). Tesis. Universitas Diponegoro. Semarang.

6. Srinivas, S., Venkanna, B., Madan Mohan, E., dan Krishna Mohan. 20I2. Urolithiasis: Overview. International Journal Of Pharmaceutical Research And Biomedical Analysis. I(I):2278-2664.

7. Sulistiyowati, Retno., Onny Setiani., dan Nurjazuli. 2013. Faktor Risiko Yang Berhubungan Dengan Kejadian Kristal Batu Saluran Kemih di Desa Mrisi Kecamatan Tanggungharjo Kabupaten Grobogan. Jurnal Kesehatan Lingkungan Indonesia. 12(2):.99105.

8. Soueidan, Michael., Susan J. Bartlett., Yasser A. Noureldin., Ross E. Anderse., dan Sero Andonian. 2015. Leisure time physical activity, smoking and risk of recent symptomatic urolithiasis: Survey of stone clinic patients. 9 (I I).

9. World Health Organization. 2020. Obesity and overweight [online]. Tersedia di: https://www.who.int/news-room/factsheets/detail/obesity-and-overweight. (diakses pada 07-06-2020).

10. Ghazaleh, Lara A A., dan Budair, Zahran. 2013. The Relation between Stone Disease and Obesity in Jordan. 24(3):610-614.

II. Sofia, Nalini H., Manickavasakam K.,Thomas M Walter. 2016. Prevalence And Risk Factors Of Kidney Stone. 5(3).

12. Agustin, One A., Soebhali, Boyke., Leatemia, Lukas D., dan Ismail, Sjarif. 2019. Hubungan Hipertensi Dan Obesitas Dengan Pasien Batu Saluran Kemih Pada Pasien Poliklinik Urologi Di Rsud Abdul Wahab Sjahranie Samarinda. I(I):28-34.

13. Nurfitriani, dan Anak Agung Gde Oka. 2019. Usia dan obesitas berhubungan terhadap penyakit batu saluran kemih di RSUP Sanglah Denpasar periode Januari 20I4 sampai Desember 2014. 10(2):258262.

14. Sorensen, Matthew D., Chi, Thomas., Shara, Nawar M., Wang, Hong., His, Ryan S., Orchard, Tonya., Kahn, Arnold J., Jackson, Rebecca D., Miller, Joe., Reiner, Alex P., dan Stoller, Marshall L. 20I4. Activity, Energy Intake, Obesity, and the Risk 
of Incident Kidney Stones in Postmenopausal Women: A Report from the Women's Health Initiative. 362369.

15. Shrivastava, Surendra K., Songra, Mool C., dan Jain, Romil. 2016. Association of body mass index, urinary $\mathrm{pH}$ and urolithiasis. 3(3): $1598-1602$.

16. Almannie, Raed M., AL-Nasserl, Khalid A., AlBarraq, Khalid M., Alsheheli, Muaath M.,. AlHazmi, Hamdan H., Binsaleh, Saleh A., Althunayan, Abdulaziz M., Alomar, Mohammed A. 2020. The effect of the body mass index on the types of urinary tract stones. 2(I):42-48

17. Fazriyah, La'elatul., Azam, Mahalul., Septiani, Indah., dan Wijayanti , Yuni. 2019. Association of Metabolic Syndrome Parameters with Kidney Stones in Indonesia. 8(2).

18. Najeeb, Qazi., Masood, Imran ., Bhaskar, Neeru., Kaur, Harnam ., Singh, Jasbir., Pandey, Rajesh ., Sodhi, K. S., Prasad, Suvarna., Ishaq, Sheikh., dan Ruhi. 2013. Effect of $B M I$ and Urinary $p H$ on Urolithiasis and lts Composition. 24(I):60-66.

19. Shavit, Linda., Ferraro, P Manuel., Johri, Nikhil., Robertson, William., Walsh, Steven B., Moochhala', Shabbir ., dan Unwin, Robert. 2015. Effect of being overweight on urinary metabolic risk factors for kidney stone formation. 607-6I3.

20. N, Anhar H., dan A, Widianto. 20I4. Index Massa Tubuh Sebagai Faktor Resiko Terjadinya Batu Saluran Kemih di RS Muslimat Ponorogo dalam Kurun Waktu Januari 2007 - Desember 2010. 6(2):75-84.

21. Wrobel, Beate M., Schubert, Gernot., Ho“rmann, Markus., dan Strohmaier, Walter L. $201 \mathrm{I}$. Overweight and Obesity: Risk Factors in Calcium Oxalate Stone Disease.

22. Mostafavi, S.R. Saadat., Bagheri, S.M., Shekari, I., dan Shekari, A. 2018. The severity of visceral obesity is associated with an increased risk of urolithiasis. 35(I): 106-II0.

23. Sopińska, Malgorzata., Wawrzyniak, Agata., Jobs, Katarzyna., dan Kalicki, Boleslaw. 2019. Urolithiasis in patients with normal and high body mass: a singlecentre study. |5(2):|45-|5|.

24. Akarken, Ilker., Tarhan, Hüseyin., Ekin, Rahmi G., Çakmak, Özgür., Koç, Gökan., İlbey, Yusuf Ö., dan Zorlu, Ferruh. 20I5. Visceral obesity: A new risk factor for stone disease. 9(I I-I 2): 795-799.
25. Beigh, Seerat H., dan Jain, Saroj. 20I2. Prevalence of metabolic syndrome and gender differences. 8(13):613-616.

26. Dewi, Dewa Ayu Putu Rasmika., dan Anak Agung Ngurah Subawa. 2017. Profil Analisis Batu Saluran Kencing di Instalasi Laboratorim Klinik RSUP Sanglah Denpasar. 8(3):205-209.

27. Hasin, Ardiansah., dan Zain, Rachmadana. 2019. Analisis Kadar Kalsium Oksalat $\left(\mathrm{Ca}_{2} \mathrm{O}_{4}\right)$ Pada Daun Dan Batang Tanaman Bayam Di Pasar Tradisional Kota Makassar. 9(I).

28. Siswanto. 2010. Systematic Review Sebagai Metode Penelitian Untuk mensistesis Hasil-Hasil Penelitian. Buletin Penelitian Sistem Kesehatan. 13(4).

29. Trisnawati, Elly., dan Jumenah. 2018. Konsumsi Makanan Yang Berisiko Terhadap Kejadian Batu Saluran Kemih. Jurnal Vokasi Kesehatan. 4(I):4650.

30. Upadhyay, Rohit., Mahmood, Khalid., Kumar, Amit ., Singh, Kamalkant., dan Prabhat. 2019. Assessment on risk factors and incidence of renal stones. International Journal of Medical and Health Research. $5(1): 136-138$. 